
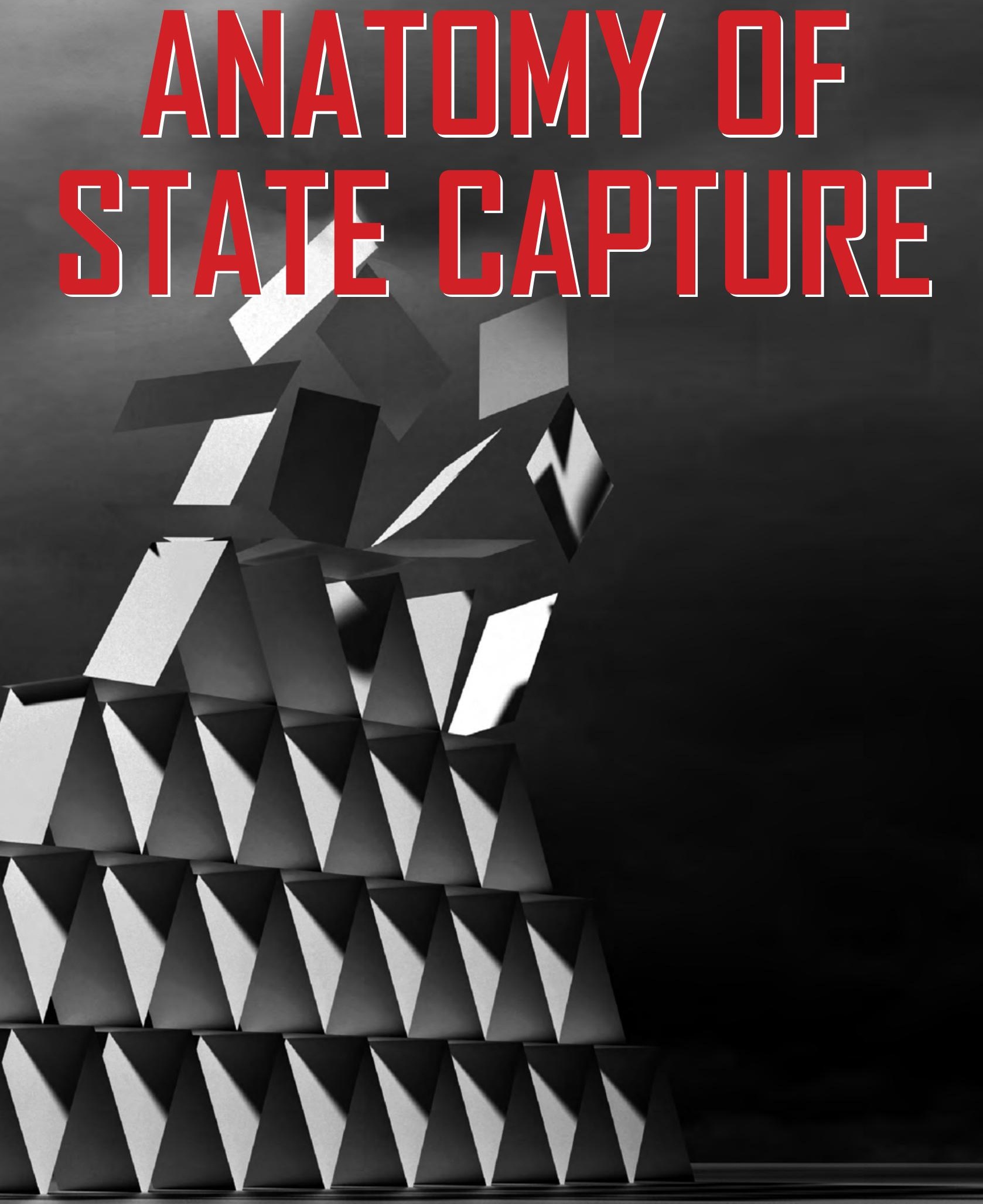

Nina Callaghan, Rabyn Foley and Mark Swilling (EDITuRS) 


\section{FINAL REFLECTIONS BY THE EDITORS}

Nina Callaghan, Robyn Foley and Mark Swilling

When we started the journey of compiling this book some two and half years ago, Anatomy of State Capture was intended to serve as an "update" of the Betrayal of the Promise (Bhorat, Buthelezi, Chipkin, Duma, Mondi, Peter, Qobo, Swilling \& Friedenstein, 2017). Much of the information presented in the various chapters was still emerging through the various investigations, inquiries and court cases. At the time of going to the publishers, the Zondo Commission is yet to complete its work and there will undoubtedly be more revelations to emerge in the years to come. The story of State Capture in South Africa is far from over. When we gathered the group of contributors to discuss the content and reflect on the progress (or rather changes) that had occurred since the release of the Betrayal report, we realised that even though there had been significant shifts within South Africa's political landscape, the discourse around State Capture had not shifted. What has shifted is the official acknowledgement that State Capture was - and still is - a political reality. This much was acknowledged by Cyril Ramaphosa during his evidence in chief at the Zondo Commission on 28 and 29 April 2021 in his capacity as President of the ANC (Zondo Commission, 2021b, 2021a). He described how it emerged as a term that was initially contested, but is not accepted by the ANC.

Two and a half years ago, most of the focus was on removing the "rotten apples" and cutting off the "sore thumbs", a perspective that assumed that the systems and institutions dismantled under the Zuma administration would self-correct. The assumption was that function would flow from form. This assumption incorrectly assumes that these systems were working before the Zuma administration and fails to recognise that it was these very systems that enabled State Capture in the first place. It is this prevailing stance that this book seeks to confront by providing a detailed account of what happened and how it happened across at least 10 case studies of State Capture. The second challenge which arises through the discourse on State Capture is a tendency to relegate it to being merely a form of "grand corruption". Though this is true, according to the original definition of term provided by Hellman, Jones and Kaufmann (2000), in the context of South Africa, it represents a phenomenon that has far greater implications for the nation's democratic project. 
As argued in the Introduction to this book, "State Capture is not just about corruption (though it is key). It is ultimately about the abuse of power and the dismantling of the social compact between society and those who should be considered the 'guardians of governance"'. It is not a grand conspiracy or a result of simply wanting to loot the state (though this is the most readily visible consequence of State Capture). We argue that State Capture as experienced in South Africa, was akin to a silent coup a political project.

This political project entailed the subversion of laws and repurposing of functions of the state. Most of the chapters of this book provide a detailed account of how different institutions were repurposed to achieve objectives they were not designed to achieve. The aim was to undermine the democratic systems of governance, including the controlling of rents, the weakening of accountability and maintaining of legitimacy for the power elites. These objectives are intertwined and interconnected, all serving to ultimately build, consolidate, and maintain power over the state in a way that benefited a select few. This political project is directly opposed to the vision and intention of our systems of governance set out in the constitution - it is a predatory logic that is authoritarian at its core.

State Capture is not just the explicit "breaking of the rules" or acts of criminality. It is the manipulation of the logics built into pre-existing systems. Much of the evidence flowing out of the Zondo Commission presented in this book provides us with a deeper understanding of what State Capture is all about. The appointment of loyal people to positions of power, the intentional weakening of institutions, manipulation of government policies and processes and the creation of parallel decision-making structures are now all identifiable traits of State Capture. What is still missing is an understanding of how State Capture happened. In the Introduction we suggest that the notion of 'rackets' helps to address this gap in current discourse.

We define rackets as a pattern of behaviour where individuals or groups are enrolled by racketeers to undertake some action (or inaction) for the benefit of the racketeer. The racketeer leverages emotive reasoning and coercive logics to enrol others, a convincing story based on fundamental untruths that is used to hide their true intentions and exploit others for their benefit. A racket succeeds if a believable untruth is accepted by those who need to be enrolled in the racket, which can be a select set of individuals, all the way through to the public in general. Rackets can be multilayered and occur at various levels within a system. They are self-perpetuating, selfreinforcing and self-replicating if left unchecked. State Capture is an example of what we refer to as the Racket of Predatory Power where individual instances of corruption become increasingly accepted patterns of behaviour (capture of state institutions), ultimately becoming standard practice (oligarchy/authoritarian state). 
These rackets are not consigned to the public sector/government alone. State Capture requires a blurred line between the private and public, and the participation of the full spectrum of role players and functionaries that constitute the body politic. The chapters in this book provide details of the roles of various politicians, civil servants, company Directors and Executives, auditors, lawyers, financial institutions and journalists that have enabled and executed the political project of State Capture.

As noted in the Introduction, this book is not intended to provide answers or solutions for how to rid South Africa of the scourge of State Capture; but rather to provide a foundation for the difficult discussions and complex actions needed to unravel the rackets and address the systemic causes of State Capture. This requires deep reflection beyond individuals and the single instances of malfeasance. It requires identifying the type of racket that is deployed and the level at which it is experienced. One needs to determine and acknowledge the untruth within the racket and expose the "big lie" that is used by racketeers. The underlying untruth can be exposed by considering the vested interests and the power dynamics at play, recognising the contradictions that inherently present themselves in the difference between what is 'intended', and what the outcomes are. It is equally important to identify the 'coercive feelings' (or predatory logics) that are leveraged to support the untruth. The importance of understanding these predatory logics is to realise that while there may be a "big lie" underpinning the racket, there can also be an even "bigger truth" that is often used to conceal it. Like all good cons, the story must be convincing.

Perhaps the most profound example of a racket is the mantra of "Radical Economic Transformation" that has been heard so frequently at the Zondo Commission. The bigger truth that supports this "ideological" stance is the reality that the economy of South Africa is still dominated by the white minority. We are still faced with high levels of inequality and unemployment, and transformation to a just and prosperous society for all has not been realised. Zuma's election promise was to speed up transformation. He intended to do this by leveraging preferential procurement policies and embarking on a massive infrastructure development drive. This is not necessarily a 'bad policy' (though there are legitimate debates on the effectiveness of this strategy for realising developmental state objectives). The "big lie", however, presents itself when we examine how this policy was implemented, who benefited from it and what the devastating consequences have been for both the state and South Africa more broadly. Had implementation occurred with the collective well-being of the nation in mind, the outcomes may have been different. Based on the evidence we have presented in this book, it was deployed with the narrow objectives of benefiting a select few, ensuring they escape any form of accountability or prosecution and enabling them to accumulate sufficient influence to continue exploiting positions of power and undermining government's ability to fulfil its constitutional mandate. 
The crude forms of rents extraction and accumulation (through BBEEE fronting and influence peddling) has not resulted in the promised development of a "black industrialist class" and the underlying structure of the economy has remained intact. Money looted from the state has found its way to offshore bank accounts in places like Dubai and Hong Kong, pumped into lavish homes and fast cars, squandered on extravagant holidays abroad and ultimately ended up in the pockets of luxury goods merchants (the owners of which remain mostly white or foreign). Most of the companies that benefited from the large investment drive are multi-national corporations that have no real vested interest in the country's development. One would think that these entities are the face of so-called "White Monopoly Capital", and yet they were perhaps the greatest beneficiaries under the Zuma administration. There is nothing radical about creating a small group of elites that exploit influence to accumulate wealth at the expense of the nation (we have had that for over 300 years).

As this book demonstrates, there are many rackets that enabled State Capture, and each will need to be explored and addressed individually and collectively. This is not a question that one group or individual can answer. It is in this spirit that we suggest some provocations that we hope will contribute to the ongoing discourse on South Africa's democratic project.

\section{1 "FIXING" GOVERNANCE}

Perhaps one of the most challenging aspects of State Capture is that many of the individual actions taken by members of the shadow state are not explicitly illegal or criminal. This is the stance taken by many who are fingered as State Capture actors. They assert that if the act is not illegal or criminal then the individual has done nothing wrong. This reductionist logic fails to recognise that just because something is not illegal does not make it is morally or ethically right. The conflation of legal action with ethical action has been a crucial enabling condition for State Capture.

Most of the activities that have enabled State Capture fall within the strict definitions of legal statutes. In some instances, they are a result of shortcomings in the design of the legal framework governing various institutions. An example is the case of SASSA, where the Minister had the power to override decisions taken by the CEO with no independent oversight body to prevent political interference (Foley \& Swilling, 2018). Another example is the confusion surrounding the various pieces of legislation governing the intelligence agencies and law enforcement mandates which was used in the capturing of SARS. The legislative inconsistencies were understood as far back as 2007 when the Scorpions were disbanded (Ginwala Enquiry, 2008), and yet there has been no effort made to address these shortcomings. 
As already highlighted, most of the discourse around what to do in the wake of State Capture has focused on fixing the processes and "capacitating" government by addressing the structure of institutions. Closing loopholes in legislative frameworks for procurement processes and making key appointments more transparent and participatory are all notable and necessary undertakings required to curtail State Capture, but they are not enough. Most of the 'solutions' focus on the formal (Weberian legal-rational) aspects of State Capture and fail to address the informal (relational) practices of the shadow state that subvert the formal. President Cyril Ramaphosa's testimony before the Zondo Commission in April 2021 is a case in point, where he lauds the new Political Party Funding Act as a tool that "will save our democracy". The idea is that this act will prevent party funding via procurement processes and its associated gratitude donations. When quizzed about the Bosasa donations to the ANC (an example of informal relations of the shadow state), Ramaphosa described this relationship as "anomalous" (Zondo Commission, 2021a, p. 142). The bulk of evidence presented to the Zondo Commission suggests otherwise.

\subsubsection{Radical Reforms and Reframing}

If we were to think of the evolution of South Africa's democracy, the pre- and immediate post-1994 political transition cohort were well-versed in the structural transformation agenda, while the cohort that tried to 'implement' democracy added the language of process and compliance. These languages and frameworks are inadequate for the current moment. Currently, there are several proposals to establish new institutions and programmes to specifically "deal with corruption", like as outlined in the National Anti-corruption Strategy (South African Government, 2020). The challenge is that many of the plans are thin on details. Establishing new institutions to do the work of hollowed out institutions that had been repurposed does not appear on the face of it to make much sense. The challenge is to restore purpose to the public sector and ensure that the values and logics of state functionally are carried out by competent civil servants.

New literature on building state capacity and institutional change suggests that preoccupation with 'good governance' has come about because many thought-leaders in the global multi-lateral system whose job it is to punt the notion of 'good governance' are mesmerised by the belief that structural conditions guarantee intended outcomes, a now outdated and disproven formula (Andrews, Pritchett \& Woolcock, 2017). The invitation is to focus on the institutional work inside of structures, the relational set of actors who are performance orientated around a clear mandate to deliver results. Key to this strategy is the nurturing of leaders and individuals who can drive an emergent institutional environment through their disruptions and provocations to reimagine 
new configurations that can respond to new opportunities. One could even say that State Capture actors were indeed these kinds of catalysing agents willing and able to figure out creative 'solutions' to their specific problems. Now we need a new generation motivated by a sense of justice and developmental intent. They will have to respect those systems that hold them to account. This is a scenario of institutional change where form follows function, buoyed by the momentum of successes and learning in tackling prioritised problems. Institutional work is an iterative, long haul, contextspecific undertaking. There are no options for quick-fix remedies or imitations of best-practice from elsewhere.

Corruption (and State Capture) is opportunistic, resilient and unrestrained by the constraints of bureaucracy or the formal-rational restrictions of "good governance". Programmes that seek to minimise opportunities for corruption should focus on improving the integrity of particular processes and should be designed to enable continuous learning and adaptation of the systems over time. The aim should not be to establish perfect systems that then require a compliance culture (or 'consequence management' systems) to ensure implementation. Instead, a resilient system that balances agency and process with strategic objectives is what will enable government to become an assemblage of institutions that reflects the aims values and provisions of the Constitution. Rackets are executed by those who care little about the impact their actions will have on the integrity and vitality of the wider set of complex systems they are part of. Indeed, some of them will engage in rackets, and bemoan the hollowing out of state institutions. Failing to link their own actions with state failure is caused by an absence of systems thinking. Although most will have sat through presentations by consultants of business school lecturers on complexity and systems thinking where they are told everything relates to everything else which is why one small negative action can switch a virtuous cycle into a vicious cycle; in practice, they instigate or get enrolled in rackets that have the opposite effect. By depicting the state as a complex system, we are effectively establishing the foundations for a relational ethics of co-responsibility. This is what will disrupt the current predatory logics and related rackets that enable State Capture.

\subsubsection{Private Sector Untruths}

As evident in the various chapters, the predatory logics or rackets that underpin State Capture extend beyond the state to most (if not all) institutions and sectors in society. This is particularly relevant in relation to the role of the private sector and private sector actors.

For example, there are inherent contradictions and conflicts of interest that are embedded in the business model of auditing firms. Auditors are supposed to provide unbiased 
and objective analysis of the financial reporting of an organisation. However, at the same time, they offer tax advisory and consultancy services, which is undoubtedly aimed at maximising corporate returns (which in some instances entails gaming the system). They act as booth referee and coach. Another example is the practice of consulting firms being brought in to diagnose problems within an institution, inevitably leading to them finding 'problems' which will require their services.

Increasingly, companies and corporations are starting to acknowledge that a purely extractive logic is unsustainable. This resulted in the now widely used notion of 'corporate citizenship' and the related shift from 'shareholder value' to 'stakeholder value' (with consumers, employees and citizens as the stakeholders). However, the most recent shift entails conceiving the corporation as an organisation that must have a defined purpose, specifically a financial, social and environmental purpose. Though this presents a potentially positive transition away from the predatory logics of the 'way we do business', some scepticism should be reserved. The ready deployment of public relations spin and secrecy assigned to minimising corporate risks are all logics that seek to absolve companies from responsibility for their malfeasance (example Bain in the SARS chapter).

Many corporates in South Africa have been vocal in speaking out against State Capture. However, these cries ring hollow when one considers what has happened to whistle-blowers most of whom cannot find employment.

\subsection{A PROVOCATION: IMAGING ALTERNATIVES}

\subsubsection{Reflecting on our Relationships with Power and the State}

One question that the State Capture narrative raises, but seldom addresses, is from whom has the state been captured? From the perspective of the 'ideal' democracy - the democracy envisaged by the Constitution - the answer would be 'from the people'. But from the perspective of empirical reality, 'the people' were never in control of the state understood as an assemblage of a multiplicity of actually existing institutions. The liberal ideal that we had a neutral constitutional state to start off with that was then captured by a specific power elite has never existed in South Africa, including after 1994. As Bob Jessop (2015) argues, 'the state' as such does not exist. It exists only as an ideal, a specific political project. In our case, the political project was a non-racial, non-sexist, democratic state. The actually existing state is a vast ramshackle affair of a multiplicity of institutions constituted in different ways for different purposes and shot through by numerous vested interests.

So, when we refer to 'State Capture', captured from whom by whom? Admittedly, we too have not adequately addressed this question as part of this book. The values and 
principles of democracy, as a system of governance, imply the perpetual peaceful contestation of interests and ideas within a framework that strives to ensure all voices are heard, solutions debated, and outcomes negotiated. As such democracy is not an end in itself, but rather a way of engaging our various collective formations in the constant process of reviewing the past, renewing the present and re-imagining futures. The purpose of this book is to inform this process of ongoing deliberation.

The question we address is not about how State Capture deviated from the liberal ideal, but how specific networks organise themselves to capture particular state institutions in order to repurpose them to achieve strategic ends, ranging from basic looting through to political power. For those committed to aligning state institutions with the democratic ideals of the Constitutions, it is essential that they understand how State Capture works in practice.

It is important to acknowledge the various institutions and individuals that exposed and curtailed the advancement of the State Capture project. As evident throughout the book, the role of the media and civil society in holding those in power to account should be applauded. Similarly, the independence of the judiciary often proved a bulwark against the machinations of the shadow state. The various investigations and inquiries that have followed set new precedents in terms of increased transparency and accountability, revealing several flaws in our democratic design.

The Political Party Funding Act has recently been signed into law (2021), though yet to be implemented. And though this is a major leap forward in terms of increasing the transparency of money in our politics, it will undoubtedly need further development. Related to this, there is also a call for reviewing the party-political system which we currently have in place.

Many have observed over the years that the ANC suffers a crisis of identity - it continues to carry its legacy of liberation movement and is yet to fully embrace the logics and constraints of the democratic system of government that the liberation movement made possible. As ANC President Cyril Ramaphosa admitted to the Zondo Commission, political cultures of patronage and patrimonialism are still prominent in South Africa's body politic (Zondo Commission, 2021b). A politics of personalities prevails, not a politics of purpose.

As rightfully raised by Adv. Pretorius, the purpose of the Zondo Commission is to understand how was it that State Capture was allowed to happen? It is a question that still needs to be answered by the political elite of this country. There are many people within the governing party that remain in key positions of power, both within the party and the state, which have been implicated in serious corruption and maleficence 
that go way beyond mere 'misdemeanours' (Madisa, 2021). The deafening silence from all quarters, reveals their disconnect from the realities of the current moment.

What makes a democratic state legitimate is the extent to which it is believed to be legitimate by the majority of the population. The state of our democracy is not only contingent on the capability of the state, but also the manner in which the society engages and contributes to its formation. In South Africa, as outlined in our Constitution, this occurs through political participation in voting and ongoing engagement with the state institutions.

Though some may question the value of the Zondo Commission and other investigations and inquiries that serve as the basis for this book, they are all crucial for the development of our democratic values. The people of South Africa have a right to know in whose interests decisions were made and why. The culture of secrecy, impunity and petty patrimonial politics must come to an end if our democracy is to thrive. Transparency and accountability are non-negotiable, as too are the requirements for transformative actions to be implemented to address the injustices that remain embedded in our social, economic and political systems. Our constitution is revolutionary in its design, but the values and vision that it prescribes can only materialise if embraced by those who have been elected to govern and by those with a duty to manage state institutions.

\subsubsection{Rebuilding Broken Trust: Time for a New Story}

What promise was betrayed in the fallout of State Capture? The possibility of a story, one where time moves forward, a narrative that is not mired in an eternal present where racketeers have free reign. State Capture stole a narrative that carried the hopes, ambitions and urgent developmental needs of a grossly unequal country. The danger we face is not that the story was stolen, but rather the possibility that such a fractious nation could have a story at all may have also been stolen.

The dawn of democracy in South Africa was buoyed by a story - that of a reconciled nation poised to address the spectre of injustices across all spheres of life. The new democracy, the Rainbow Nation - however remote or real to citizens - lived in our imaginations. It carried in its sweep institutional reforms, new policy, and reconfigured rules for implementation. Beset with all manner of teething problems the fledgling Mzansi continued to hold on to the idea that its social welfarism and developmental agenda could deliver jobs, greater economic and social prosperity, "a better life for all". Even when poverty increased and economic growth rates refused to improve, there was still a story - a place to put one's faith, a goal to move towards, even when the function of the state did not follow its form. 
The predatory state capitalised on the citizen's enrolment in this early story, manipulating narratives that duped many of us, for a while, into the belief that transformation was well within reach. The ruse of State Capture has cannibalised the traditional story of hope, and in the process decimated all faith that state institutions and its private sector partners are holding the other end of the social contract. We are called to stop being mesmerised by the mess we are in, by the immensity of betrayal, by the ineffectiveness of the ANC, by the hijack of race issues. We are called to seek those places where we can thrive and succeed supported by the ethics that our starkly unjust reality demands.

So where do we start with this new story in the detritus of State Capture? With a paradigm shift of prioritising specific problems and solving them for our context, bracing for a long haul of reflective practice that reaches not only into the halls of power, but into our businesses, places of learning and into our very homes to reexamine the cultures we nurture there. Instead of focusing on fear and compliance, can we build capability to succeed, the ability to implement the lauded policies we have on paper? Can we imbue this paradigm with purpose, with creating public value that is driven by performance and not self-interest? If the answer is yes, then we have started a new story - one we can own, and that the future deserves. 


\section{References}

Andrews, M., Pritchett, L. \& Woolcock, M. (2017) Building State Capability:

Evidence, Analysis, Action. Oxford: Oxford University Press. https://doi.org/10.1093/ acprof:oso/9780198747482.001.0001

Bhorat, H., Buthelezi, M., Chipkin, I., Duma, S., Mondi, L., Peter., C., Qobo, M., Swilling, M. \& Friedenstein, H. (2017) Betrayal of the Promise: How South Africa is being stolen, State Capacity Research Project. South Africa. https://bit.ly/3yxnt0v

Foley, R. \& Swilling, M. (2018) ‘How One Word Can Change the Game: Case Study of State Capture and the South African Social Security Agency', State Capacity Research Project. Stellenbosch. [Online]. https://bit. ly/31GtGnq (Accessed 6 August 2018).

Ginwala Enquiry (2008) 'Report of Enquiry into the fitness of Advocate VP Pikoli to hold the office of National Director of Public Prosecutions. Pretoria. https://bit.ly/ 2X05P7L

Hellman, J., Jones, G. \& Kaufmann, D. (2000) 'Seize the State, Seize the Day: An Empirical Analysis of State Capture and Corruption in Transition Economies', World Bank Policy Research Working Paper. Washington, D.C.
[Online]. papers2://publication/uuid/ B15B06FA-4346-4788-A9CB-C0743 1F4B63A

Jessop, B. (2015) The State: Past, Present, Future. Cambridge and Malden: Polity Press.

Madisa, K. (2021) 'ANC NEC's busy weekend of decisions - and it spells bad news for Magashule, Times Live. [Online]. https://bit. ly/3yxFfke (Accessed 4 May 2021).

South African Government (2020) National Anti-Corruption Strategy. [Online]. https:// www.gov.za/zu/AntiCorruption (Accessed 4 May 2021).

The Presidency (2021) 'President Ramaphosa signs Political Party Funding Act into operation', The Presidency. [Online]. https:// bit.ly/3CsuceI (Accessed 4 May 2021).

Zondo Commission (2021a) 'Transcript from Inquiry into State Capture: Day 384 (28-04-2021) - Testimony of Cyril Ramaphosa', Commission of Inquiry into State Capture.

Zondo Commission (2021b) 'Transcript from Inquiry into State Capture: Day 385 (29-04-2021) - Testimony of Cyril Ramaphosa', Commission of Inquiry into State Capture. 



\section{APPENDIX}

\begin{tabular}{|c|c|c|c|c|}
\hline $\begin{array}{l}\text { Case Study } \\
\text { in State } \\
\text { Capture }\end{array}$ & Status & Summary Description & $\begin{array}{l}\text { Investigation } \\
\text { Body / } \\
\text { Source of } \\
\text { Evidence }\end{array}$ & $\begin{array}{l}\text { Government } \\
\text { Entity } \\
\text { Implicated }\end{array}$ \\
\hline \multicolumn{5}{|c|}{ Scandals Connected to Jacob Zuma, Guptas, Other Key Networks and ANC Politics } \\
\hline $\begin{array}{l}\text { The State } \\
\text { of Capture } \\
\text { report- } \\
\text { focuses } \\
\text { on Guptas' } \\
\text { relationship } \\
\text { with Jacob } \\
\text { Zuma and } \\
\text { their alleged } \\
\text { influence on } \\
\text { the affairs } \\
\text { of state }\end{array}$ & $\begin{array}{l}\text { First complaint } \\
\text { was received } \\
\text { in March } 2016 \\
\text { and the report } \\
\text { was released in } \\
\text { November } 2016 .\end{array}$ & $\begin{array}{l}\text { Investigation into complaints of alleged improper } \\
\text { and unethical conduct by the President and } \\
\text { other State Functionaries, relating to alleged } \\
\text { improper relationships and involvement of the } \\
\text { Gupta Family in the removal and appointment } \\
\text { of Ministers and Directors of State-Owned } \\
\text { Enterprises (SOEs), resulting in improper and } \\
\text { possibly corrupt award of State Contracts and } \\
\text { Benefits to the Gupta Family's Businesses. } \\
\text { The report details numerous allegations of } \\
\text { the Guptas' involvement in affairs of the state } \\
\text { and their irregular activities that enable rent } \\
\text { extraction. The findings were not conclusive } \\
\text { and the remedial action was to establish a } \\
\text { commission of inquiry into state capture (to } \\
\text { be appointed by the President, but with a } \\
\text { judge selected by the Chief Justice). Litigation } \\
\text { endeavoured to delay or prohibit the report's } \\
\text { release and implementation of remedial actions, } \\
\text { but failed, and the commission was established } \\
\text { in } 2018 \text {. }\end{array}$ & $\begin{array}{l}\text { - Public } \\
\text { Protector, } \\
\text { followed by } \\
\text { litigation }\end{array}$ & $\begin{array}{l}\text { - GCIS (The } \\
\text { New Age) } \\
\text { - Eskom } \\
\text { (Optimum) } \\
\text { - Transnet } \\
\text { (Regiments/ } \\
\text { Trillian) } \\
\text { - Denel } \\
\text { - SAA (The } \\
\text { New Age) } \\
\text { - SABC (The } \\
\text { New Age) } \\
\text { - Department of } \\
\text { Finance } \\
\text { - Transport } \\
\text { (SAA) } \\
\text { - Communica- } \\
\text { tions (SABC } \\
\text { \& GCIS) }\end{array}$ \\
\hline $\begin{array}{l}\text { Zondo } \\
\text { Commission }\end{array}$ & $\begin{array}{l}\text { Established } \\
\text { in 2018, with } \\
\text { anticipated } \\
\text { conclusion being } \\
\text { the end of } 2021 .\end{array}$ & $\begin{array}{l}\text { Formally titled the Judicial Commission of } \\
\text { Inquiry into Allegations of State Capture, } \\
\text { Corruption and Fraud in the Public Sector } \\
\text { including Organs of State, the Commission } \\
\text { was promulgated by then President Zuma in } \\
\text { response to the remedial actions as outlined in } \\
\text { the Public Protector's State of Capture report. } \\
\text { As of June } 2021 \text {, the Commission that started } \\
\text { in August } 2018 \text { has held more than } 418 \text { days } \\
\text { of hearings of over } 330 \text { testimonies (generating } \\
\text { over } 71000 \text { pages of transcript). The inquiry's } \\
\text { terms of reference were expansive and, as } \\
\text { such, the scope of investigations went beyond } \\
\text { merely looking into the Gupta-related cases, } \\
\text { covering other networks (e.g., Bosasa) as well } \\
\text { as other government institutions (e.g., role } \\
\text { of Parliament). }\end{array}$ & $\begin{array}{l}\text { - Zondo } \\
\text { Commission }\end{array}$ & $\begin{array}{l}\text { Various } \\
\text { work-streams } \\
\text { covering } \\
\text { inter alia: } \\
\text { - SOEs } \\
\text { (Eskom, } \\
\text { Transnet, } \\
\text { Denel, SAA) } \\
\text { - Free State } \\
\quad \text { Provincial } \\
\text { Government } \\
\text { - Bosasa } \\
\text { - SARS } \\
\text { - Law } \\
\text { enforcement } \\
\text { - State Security } \\
\text { Agency (SSA) } \\
\text { - The New Age } \\
\text { \& ANN7 } \\
\text { - Role of } \\
\text { Parliament } \\
\text { and ANC }\end{array}$ \\
\hline
\end{tabular}




\begin{tabular}{|c|c|c|c|c|}
\hline $\begin{array}{l}\text { Case Study } \\
\text { in State } \\
\text { Capture }\end{array}$ & Status & Summary Description & $\begin{array}{l}\text { Investigation } \\
\text { Body / } \\
\text { Source of } \\
\text { Evidence }\end{array}$ & $\begin{array}{l}\text { Government } \\
\text { Entity } \\
\text { Implicated }\end{array}$ \\
\hline \multicolumn{5}{|c|}{ Scandals Connected to Jacob Zuma, Guptas, Other Key Networks and ANC Politics } \\
\hline Bosasa & $\begin{array}{l}\text { Dating back to a } \\
2009 \text { SIU report. } \\
\text { Investigations and } \\
\text { various litigations } \\
\text { are ongoing. }\end{array}$ & $\begin{array}{l}\text { In 2019, former Bosasa C00, Anglo Agrizzi, } \\
\text { testified at the Zondo Commission, detailing } \\
\text { the acts and long history of corruption between } \\
\text { various Bosasa companies predominantly } \\
\text { owned by Gavin Watson, and numerous } \\
\text { government entities/departments. The } \\
\text { testimony of Agrizzi (and other former Bosasa } \\
\text { employees) corroborated the findings of a } \\
2009 \text { SIU investigation that alleged corruption } \\
\text { in several contracts Bosasa had with the } \\
\text { Department of Correctional Services. Criminal } \\
\text { court proceedings have been initiated based } \\
\text { on the } 2009 \text { SIU investigation, along with new } \\
\text { investigations initiated by SARS and other law } \\
\text { enforcement entities. }\end{array}$ & $\begin{array}{l}\text { - Special } \\
\text { Investi- } \\
\text { gation } \\
\text { Unit (SIU) } \\
\text { - Zondo } \\
\text { Commission }\end{array}$ & $\begin{array}{l}\text { - Department of } \\
\text { Correctional } \\
\text { Services } \\
\text { - Department of } \\
\text { Justice } \\
\text { - Department of } \\
\text { Home Affairs } \\
\text { - Department of } \\
\text { Transport } \\
\text { - Various SOEs } \\
\text { (e.g., SAPO, } \\
\text { ACSA) } \\
\text { - National } \\
\text { Prosecuting } \\
\text { Authority } \\
\text { (NPA) } \\
\text { - Members of } \\
\text { Parliament }\end{array}$ \\
\hline Arms Deal & $\begin{array}{l}\text { Various } \\
\text { investigations and } \\
\text { sources, dating } \\
\text { back to 1990s. } \\
\text { Most significant } \\
\text { source being } \\
\text { through Seriti } \\
\text { Commission. } \\
\text { Corruption case } \\
\text { against Zuma is } \\
\text { ongoing. }\end{array}$ & $\begin{array}{l}\text { Commission of Inquiry into allegations of fraud, } \\
\text { corruption, impropriety, or irregularity in the } \\
\text { Strategic Defence Procurement Packages } \\
\text { (SDPP). Various court cases related to } \\
\text { allegations of corruption against Jacob Zuma. } \\
\text { On Monday, } 24 \text { October 2011, the President } \\
\text { announced the Commission chaired by Judge } \\
\text { Seriti. The findings of the Commission were that } \\
\text { there was "no evidence" of corruption, but this } \\
\text { is seen by many to have been a whitewash. The } \\
\text { report was taken on review and set aside in } \\
\text { August 2019. The corruption case against Zuma } \\
\text { is ongoing before the courts. }\end{array}$ & $\begin{array}{l}\text { - Seriti } \\
\text { Commission } \\
\text { - Various } \\
\text { court cases }\end{array}$ & $\begin{array}{l}\text { Initially: } \\
\text { - South African } \\
\text { National } \\
\text { Defence } \\
\text { Force } \\
\text { - Members of } \\
\text { Parliament } \\
\text { Allegations also } \\
\text { involve: } \\
\text { - NPA } \\
\text { - SSA }\end{array}$ \\
\hline $\begin{array}{l}\text { Nkandla } \\
\text { Security } \\
\text { Upgrades }\end{array}$ & $\begin{array}{l}\text { Investigation } \\
\text { started in } \\
\text { November } 2012 . \\
\text { Report on } \\
\text { investigation } \\
\text { was released in } \\
\text { March } 2014 .\end{array}$ & $\begin{array}{l}\text { Report on security upgrades to President } \\
\text { Zuma's homestead in Nkandla. The investigation } \\
\text { found that the President unduly benefited from } \\
\text { the upgrades and as part of remedial actions } \\
\text { the President was required to pay back a portion } \\
\text { of the costs of the upgrades. Zuma instructed } \\
\text { that SAPS undertake their own investigation, } \\
\text { which sought to rationalise the expenses (fire- } \\
\text { pool report). Parliament accepted this alternative } \\
\text { report, but major court cases followed, } \\
\text { ultimately declaring that the Public Protector's } \\
\text { remedial actions are binding. President and } \\
\text { Parliament failed to uphold the Constitution. } \\
\text { President ordered to "pay back the money". }\end{array}$ & $\begin{array}{l}\text { - Public } \\
\text { Protector's } \\
\text { Secured } \\
\text { in Comfort } \\
\text { report, } \\
\text { followed by } \\
\text { litigation }\end{array}$ & $\begin{array}{l}\text { - Department of } \\
\text { Public Works } \\
\text { - South African } \\
\text { Police Service }\end{array}$ \\
\hline
\end{tabular}




\begin{tabular}{|c|c|c|c|c|}
\hline $\begin{array}{l}\text { Case Study } \\
\text { in State } \\
\text { Capture }\end{array}$ & Status & Summary Description & $\begin{array}{l}\text { Investigation } \\
\text { Body / } \\
\text { Source of } \\
\text { Evidence }\end{array}$ & $\begin{array}{l}\text { Government } \\
\text { Entity } \\
\text { Implicated }\end{array}$ \\
\hline \multicolumn{5}{|c|}{ Scandals Connected to Jacob Zuma, Guptas, Other Key Networks and ANC Politics } \\
\hline $\begin{array}{l}\text { Private } \\
\text { Aircraft } \\
\text { Landing at } \\
\text { Waterkloof } \\
\text { Airforce Base } \\
\text { and Gupta } \\
\text { Sun City } \\
\text { Wedding }\end{array}$ & May 2013. & $\begin{array}{l}\text { In 2013, justice, crime prevention, and } \\
\text { security cluster (JCPS) - a cabinet structure } \\
\text { composed of various ministries - undertook an } \\
\text { investigation into the Landing of a Commercial } \\
\text { aircraft at Air Force Base Waterkloof (report } \\
\text { titled the same). The investigation revealed that } \\
\text { the Guptas initially tried to organise a special } \\
\text { landing at OR Tambo International Airport, but } \\
\text { was turned down. They then approached the } \\
\text { Indian High Commission who re-designated the } \\
\text { wedding entourage as an official delegation to } \\
\text { secure a landing at the Waterkloof base. The } \\
\text { wedding held at Sun City was attended by a } \\
\text { number of high-profile ANC politicians and was } \\
\text { paid for in part by moneys looted from the Vrede } \\
\text { Dairy Farm project. }\end{array}$ & $\begin{array}{l}\text { - Report by } \\
\text { JPCS } \\
\text { - Zondo } \\
\text { Commission } \\
\end{array}$ & \begin{tabular}{|l} 
- Department of \\
International \\
Relations and \\
Cooperation \\
(DIRCO) \\
- Department of \\
Defence \\
- Department of \\
Transport
\end{tabular} \\
\hline $\begin{array}{l}\text { Free State } \\
\text { Provincial } \\
\text { Capture, } \\
\text { includes } \\
\text { Vrede Dairy } \\
\text { Farm and } \\
\text { Asbestos } \\
\text { Contracts }\end{array}$ & Ongoing. & $\begin{array}{l}\text { The Vrede Dairy Farm project was initiated } \\
\text { by the Free State Provincial Government as a } \\
\text { development project, however, in partnering with } \\
\text { a Gupta-linked company Estina, government } \\
\text { funds were looted. In 2018, the Public } \\
\text { Protector released a report on their } 2018 \\
\text { investigation, but it was taken on review and } \\
\text { set aside by the courts. The second part of the } \\
\text { investigation is yet to be finalised. The NPA } \\
\text { laid criminal charges against Gupta associates } \\
\text { and implicated government officials. Court } \\
\text { proceedings are ongoing. } \\
\text { Significant testimony and evidence have been } \\
\text { presented at the Zondo Commission regarding } \\
\text { the Vrede Farm case, as well as the asbestos } \\
\text { inspection project (criminal proceedings are also } \\
\text { underway). Both projects implicate high-profile } \\
\text { politicians and senior officials manipulating } \\
\text { government process. }\end{array}$ & $\begin{array}{l}\text { - Public } \\
\text { Protector } \\
\text { reports } \\
\text { - Zondo } \\
\text { Commission } \\
\text { - Various } \\
\text { court cases } \\
\end{array}$ & $\begin{array}{l}\text { - Free State } \\
\text { Provincial } \\
\text { Government }\end{array}$ \\
\hline $\begin{array}{l}\text { Irregular } \\
\text { removal of } \\
\text { National } \\
\text { Director } \\
\text { of Public } \\
\text { Prosecutions } \\
\text { (NDPP), } \\
\text { Mxolisi } \\
\text { Nxasana }\end{array}$ & $\begin{array}{l}\text { Inquiry instituted } \\
\text { in February } 2015, \\
\text { but was cancelled } \\
\text { in May } 2015 . \\
\text { This triggers the } \\
\text { Constitutional Court } \\
\text { cases that followed. }\end{array}$ & $\begin{array}{l}\text { Inquiry into the fitness of Mxolisi Nxasana to } \\
\text { hold office as NDPP. The Inquiry was cancelled } \\
\text { after Zuma "agreed to let Nxasana resign". He } \\
\text { was paid R17m - the balance of his ten-year } \\
\text { contract. Court cases followed detailing the } \\
\text { abuse of the presidency powers by Zuma. } \\
\text { Ultimately, Nxasana was ordered to repay } \\
\text { R17m and Zuma's appointed replacement, } \\
\text { Shawn Abrahams, was ordered to vacate office. } \\
\text { Constitutional Court found Zuma's actions to } \\
\text { be an abuse of power and in breach of his } \\
\text { constitutional obligations. }\end{array}$ & $\begin{array}{l}\text { - Cassim } \\
\text { Inquiry into } \\
\text { fitness of } \\
\text { Mxolisi } \\
\text { Nxasana to } \\
\text { hold office } \\
\text { of NDPP } \\
\text { initiated } \\
\text { by Zuma, } \\
\text { followed by } \\
\text { litigation }\end{array}$ & $\begin{array}{l}\text { - National } \\
\text { Prosecution } \\
\text { Authority }\end{array}$ \\
\hline $\begin{array}{l}\text { Political } \\
\text { killings in } \\
\text { KZN }\end{array}$ & $\begin{array}{l}\text { Established in } \\
\text { October } 2016 . \text { The } \\
\text { report was released } \\
\text { in May } 2018 .\end{array}$ & $\begin{array}{l}\text { On } 28 \text { October 2016, the Premier of the } \\
\text { Province of KwaZulu-Natal established a } \\
\text { Commission of Enquiry into the Underlying } \\
\text { Causes of the Murder of Politicians in KwaZulu- } \\
\text { Natal (KZN). }\end{array}$ & $\begin{array}{l}\text { - Moerane } \\
\text { Commission } \\
\text { of Enquiry }\end{array}$ & $\begin{array}{l}\text { - KZN Provincial } \\
\text { Government } \\
\text { - KZN Local } \\
\text { Governments }\end{array}$ \\
\hline
\end{tabular}




\begin{tabular}{|c|c|c|c|c|}
\hline $\begin{array}{l}\text { Case Study } \\
\text { in State } \\
\text { Capture }\end{array}$ & Status & Summary Description & $\begin{array}{l}\text { Investigation } \\
\text { Body / } \\
\text { Source of } \\
\text { Evidence }\end{array}$ & $\begin{array}{l}\text { Government } \\
\text { Entity } \\
\text { Implicated }\end{array}$ \\
\hline \multicolumn{5}{|c|}{ Scandals Connected to Jacob Zuma, Guptas, Other Key Networks and ANC Politics } \\
\hline \multicolumn{5}{|c|}{ State Capture of State-Owned Enterprises and Government Departments } \\
\hline $\begin{array}{l}\text { Interference } \\
\text { in operations } \\
\text { at the SABC }\end{array}$ & $\begin{array}{l}\text { The Ad Hoc } \\
\text { Committee was } \\
\text { established in } \\
\text { November } 2016 \\
\text { and final report } \\
\text { was tabled on } \\
24 \text { February } 2017 .\end{array}$ & $\begin{array}{l}\text { Parliamentary Ad Hoc Committee on the } \\
\text { SABC Board Inquiry into mismanagement and } \\
\text { interference in SABC operations. Findings } \\
\text { include evidence of Minister Faith Muthambi's } \\
\text { interference in the organisation and editorial } \\
\text { interference, in the firing of SABC } 8 \text { who } \\
\text { protested censorship of the national broadcaster } \\
\text { (on instruction from COO Hlaudi Motsoeneng). It } \\
\text { should be noted that the inquiry was preceded } \\
\text { by an investigation by the Public Protector. } \\
\text { Details are contained in the } 2014 \text { report titled } \\
\text { When Governance and Ethics Fail. }\end{array}$ & $\begin{array}{l}\text { - Parliamen- } \\
\text { tary Inquiry } \\
\text { - Preceded by } \\
\text { an investi- } \\
\text { gation by } \\
\text { the Public } \\
\text { Protector }\end{array}$ & $\begin{array}{l}\text { - SABC } \\
\text { (Department } \\
\text { of Communi- } \\
\text { cation) }\end{array}$ \\
\hline \multirow[t]{2}{*}{$\begin{array}{l}\text { Passenger } \\
\text { Rail Agency } \\
\text { of South } \\
\text { Africa } \\
\text { (PRASA) }\end{array}$} & $\begin{array}{l}\text { Complaints were } \\
\text { lodged in } 2012 \\
\text { and the report } \\
\text { was released in } \\
\text { August } 2015 \text {. }\end{array}$ & $\begin{array}{l}\text { Several cases of "mismanagement and } \\
\text { irregularities" regarding various contracts. } \\
\text { Lucky Montana was CEO at the time. One of } \\
\text { the remedial actions stipulated that National } \\
\text { Treasury was to investigate all PRASA contracts } \\
\text { from } 2012 \text { onwards with a value of R10 million } \\
\text { or more. National Treasury implemented the } \\
\text { remedial action which resulted in several } \\
\text { investigations, the details of which were leaked } \\
\text { to the public. }\end{array}$ & $\begin{array}{l}\text { - Public } \\
\text { Protector's } \\
\text { Derailed } \\
\text { report on } \\
\text { PRASA } \\
\text { - Numerous } \\
\text { investiga- } \\
\text { tions }\end{array}$ & $\begin{array}{l}\text { - PRASA } \\
\text { - Department of } \\
\text { Transport }\end{array}$ \\
\hline & $\begin{array}{l}\text { In June } 2017, \\
\text { Parliament directed } \\
4 \text { committees to } \\
\text { investigate state } \\
\text { capture. Committee } \\
\text { hearings were not } \\
\text { completed. }\end{array}$ & $\begin{array}{l}\text { In terms of the parliamentary directive, the } \\
\text { Portfolio Committee on Transport was requested } \\
\text { to establish an Inquiry into State Capture at } \\
\text { PRASA. However, the Portfolio Committee noted } \\
\text { that PRASA was not mentioned in the Public } \\
\text { Protector's State of Capture report and decided } \\
\text { they would focus on the various investigation } \\
\text { reports produced for National Treasury (as } \\
\text { recommended in Derailed report). }\end{array}$ & $\begin{array}{l}\text { - Portfolio } \\
\text { Committee } \\
\text { on Transport }\end{array}$ & $\begin{array}{l}\text { - PRASA } \\
\text { - Department of } \\
\text { Transport }\end{array}$ \\
\hline $\begin{array}{l}\text { Eskom } \\
\text { Inquiry into } \\
\text { State Capture }\end{array}$ & $\begin{array}{l}\text { In June } 2017 \text {, } \\
\text { Parliament directed } \\
4 \text { committees } \\
\text { to investigate } \\
\text { state capture. } \\
\text { Public Enterprises } \\
\text { Committee } \\
\text { report on Eskom } \\
\text { was released in } \\
\text { November } 2018 .\end{array}$ & $\begin{array}{l}\text { Extensive hearings were held by the Committee } \\
\text { detailing much of the evidence presented in } \\
\text { the Public Protector's report. The Committee } \\
\text { presented recommendations and compiled } \\
\text { a final report detailing their findings. These } \\
\text { included findings that Ministers Lynne Brown } \\
\text { and Malusi Gigaba were negligent and had to } \\
\text { be held accountable. Also recommended that } \\
\text { criminal investigations be undertaken against } \\
\text { the relevant Eskom executives. }\end{array}$ & $\begin{array}{l}\text { - Parliamen- } \\
\text { tary Inquiry }\end{array}$ & $\begin{array}{l}\text { - Eskom } \\
\text { - Department } \\
\text { of Public } \\
\text { Enterprises }\end{array}$ \\
\hline $\begin{array}{l}\text { Nugent } \\
\text { Commission } \\
\text { - SARS } \\
\text { Inquiry }\end{array}$ & $\begin{array}{l}\text { The Inquiry was } \\
\text { constituted on } \\
24 \text { May } 2018 \text { and } \\
\text { the final report } \\
\text { was released in } \\
\text { December } 2018 \text {. }\end{array}$ & $\begin{array}{l}\text { Commission of Inquiry into tax administration } \\
\text { and governance by South African Revenue } \\
\text { Service (SARS). Tom Moyane was fired based on } \\
\text { the interim report released in September } 2018 . \\
\text { The inquiry found that Moyane, with the help of } \\
\text { consultancy company Bain, had implemented } \\
\text { restructuring of the organisation, resulting in } \\
\text { gross mismanagement and erosion of SARS. } \\
\text { Moyane motivated the restructuring based on } \\
\text { the "rogue unit" narrative that has been the } \\
\text { subject of several other debunked investigations } \\
\text { and the subject of much litigation. }\end{array}$ & $\begin{array}{l}\text { - Judicial } \\
\text { Commission } \\
\text { of Inquiry } \\
\text { - Court cases } \\
\text { around the } \\
\text { "rogue unit" } \\
\text { narrative }\end{array}$ & $\begin{array}{l}\text { - SARS } \\
\text { (National } \\
\text { Treasury) }\end{array}$ \\
\hline
\end{tabular}




\begin{tabular}{|c|c|c|c|c|}
\hline $\begin{array}{l}\text { Case Study } \\
\text { in State } \\
\text { Capture }\end{array}$ & Status & Summary Description & $\begin{array}{l}\text { Investigation } \\
\text { Body / } \\
\text { Source of } \\
\text { Evidence }\end{array}$ & $\begin{array}{l}\text { Government } \\
\text { Entity } \\
\text { Implicated }\end{array}$ \\
\hline \multicolumn{5}{|c|}{ Scandals Connected to Jacob Zuma, Guptas, Other Key Networks and ANC Politics } \\
\hline \multicolumn{5}{|c|}{ State Capture of State-Owned Enterprises and Government Departments } \\
\hline $\begin{array}{l}\text { Commission } \\
\text { of Inquiry } \\
\text { into Public } \\
\text { Investment } \\
\text { Corporation } \\
\text { (PIC) }\end{array}$ & $\begin{array}{l}\text { In October } 2018 \text {, } \\
\text { the Commission } \\
\text { was constituted, } \\
\text { and the final report } \\
\text { was released in } \\
\text { March } 2020 .\end{array}$ & $\begin{array}{l}\text { Commission of Inquiry into allegations of } \\
\text { impropriety regarding Public Investment } \\
\text { Corporation (PIC). There were extensive hearings } \\
\text { on various 'dodgy' deals the PIC entered } \\
\text { into and details of political and executive } \\
\text { interference in the operations and decision- } \\
\text { making processes of the investment agency. }\end{array}$ & $\begin{array}{l}\text { - Judicial } \\
\text { Commission } \\
\text { of Inquiry }\end{array}$ & $\begin{array}{l}\text { - PIC (National } \\
\text { Treasury) }\end{array}$ \\
\hline $\begin{array}{l}\text { South African } \\
\text { Social } \\
\text { Security } \\
\text { Agency } \\
\text { (SASSA) }\end{array}$ & $\begin{array}{l}\text { Various } \\
\text { Constitutional Court } \\
\text { cases from } 2011 \\
\text { to } 2018 \text { resulted } \\
\text { in removal of CPS } \\
\text { as service provider } \\
\text { to SASSA. }\end{array}$ & $\begin{array}{l}\text { In 2014, South African Social Security Agency's } \\
\text { (SASSA) } 2012 \text { contract with CPS was found } \\
\text { to be irregular and invalid, however, due to the } \\
\text { importance of ensuring beneficiaries received } \\
\text { grants, CPS continued to be the service } \\
\text { providers until } 2018 \text {. Following a March } 2017 \\
\text { ruling, the Constitutional Court instituted a } \\
\text { Section } 38 \text { Inquiry into Minister Bathabile } \\
\text { Dlamini's personal liability for the narrowly } \\
\text { averted grant payment crisis. }\end{array}$ & $\begin{array}{l}\text { Primary } \\
\text { sources: } \\
\text { - AllPay court } \\
\text { case } \\
\text { - Black Sash } \\
\text { court case }\end{array}$ & - SASSA \\
\hline $\begin{array}{l}\text { South African } \\
\text { Airways (SAA) } \\
\text { and SAA } \\
\text { Technical }\end{array}$ & $\begin{array}{l}\text { Court case } \\
\text { to have Dudu } \\
\text { Myeni declared a } \\
\text { delinquent director } \\
\text { was launched } \\
\text { in } 2017 .\end{array}$ & $\begin{array}{l}\text { Court case was launched in } 2017 \text { by Outa and } \\
\text { the SAA Pilots' Association (SAAPA) to declare } \\
\text { Myeni a delinquent director in terms of the } \\
\text { Companies Act, based on her actions while she } \\
\text { was chairperson of the SAA Board. In 2020, the } \\
\text { High Court declared Myeni a delinquent director } \\
\text { for life. A significant amount of new evidence } \\
\text { also emerged through the Zondo Commission, } \\
\text { outlining how the operations at SAA were } \\
\text { undermined and how Myeni and others abused } \\
\text { their positions of authority. }\end{array}$ & $\begin{array}{l}\text { - Court } \\
\text { papers } \\
\text { - Zondo } \\
\text { Commission }\end{array}$ & $\begin{array}{l}\text { - SAA } \\
\text { - SAA Technical }\end{array}$ \\
\hline $\begin{array}{l}\text { Gupta Family } \\
\text { Naturalisation }\end{array}$ & $\begin{array}{l}\text { In June } 2017, \\
\text { Parliament directed } \\
4 \text { committees to } \\
\text { investigate state } \\
\text { capture. Final } \\
\text { report was tabled } \\
14 \text { March } 2019 .\end{array}$ & $\begin{array}{l}\text { Portfolio Committee on Home Affairs Inquiry into } \\
\text { the Gupta Family Naturalisation was established } \\
\text { in terms of the Parliamentary directive. Hearings } \\
\text { formally started on } 12 \text { September 2018. Final } \\
\text { report was tabled on } 14 \text { March 2019. Questions } \\
\text { were raised around contracts with Visa } \\
\text { Facilitation Services. This matter is ongoing as } \\
\text { of December } 2020 \text {. }\end{array}$ & $\begin{array}{l}\text { - Portfolio } \\
\text { Committee } \\
\text { on Home } \\
\text { Affairs }\end{array}$ & $\begin{array}{l}\text { - Department of } \\
\text { Home Affairs }\end{array}$ \\
\hline $\begin{array}{l}\text { Inquiry into } \\
\text { State Capture } \\
\text { related to } \\
\text { Gupta-owned } \\
\text { mines }\end{array}$ & $\begin{array}{l}\text { In June } 2017, \\
\text { Parliament directed } \\
4 \text { committees } \\
\text { to investigate } \\
\text { state capture. }\end{array}$ & $\begin{array}{l}\text { Though the Committee drafted a term of } \\
\text { reference for the Inquiry, the activities of holding } \\
\text { hearings and consolidating the evidence never } \\
\text { materialised beyond questions being put to then } \\
\text { Minister Zwane. }\end{array}$ & $\begin{array}{l}\text { - Portfolio } \\
\text { Committee } \\
\text { on Mineral } \\
\text { Resources }\end{array}$ & $\begin{array}{l}\text { - Department } \\
\text { of Mineral } \\
\text { Resources }\end{array}$ \\
\hline
\end{tabular}




\begin{tabular}{|c|c|c|c|c|}
\hline $\begin{array}{l}\text { Case Study } \\
\text { in State } \\
\text { Capture }\end{array}$ & Status & Summary Description & $\begin{array}{l}\text { Investigation } \\
\text { Body / } \\
\text { Source of } \\
\text { Evidence }\end{array}$ & $\begin{array}{l}\text { Government } \\
\text { Entity } \\
\text { Implicated }\end{array}$ \\
\hline \multicolumn{5}{|c|}{ Scandals Connected to Jacob Zuma, Guptas, Other Key Networks and ANC Politics } \\
\hline \multicolumn{5}{|c|}{ State Capture of State-Owned Enterprises and Government Departments } \\
\hline \multirow{3}{*}{$\begin{array}{l}\text { Various } \\
\text { investigations } \\
\text { relating to } \\
\text { State Capture } \\
\text { at Eskom }\end{array}$} & 2015 & $\begin{array}{l}\text { In } 2015 \text {, Dentons produced an interim report } \\
\text { on their investigations into Status of Business } \\
\text { and Challenges at Eskom. Their investigation } \\
\text { was halted. }\end{array}$ & - Eskom & - Eskom \\
\hline & \multirow[t]{2}{*}{2017} & $\begin{array}{l}\text { In 2017, PricewaterhouseCoopers (PwC) was } \\
\text { appointed by National Treasury to investigate } \\
\text { Eskom's Coal Procurement Processes. Damning } \\
\text { findings were made in relation to Gupta-owned } \\
\text { Tegeta mine contracts and poor coal quality. }\end{array}$ & - Eskom & - Eskom \\
\hline & & $\begin{array}{l}\text { G9 was contracted by Eskom to investigate } \\
\text { the Trillian/McKinsey contracts. Interim report } \\
\text { presented to Board of Eskom in August } 2017 . \\
\text { The investigation remained incomplete, and } \\
\text { no report is available in the public domain. } \\
\text { Evidence from the investigation was presented } \\
\text { in the Parliamentary Inquiry into Eskom } \\
\text { State Capture. }\end{array}$ & $\begin{array}{l}\text { - National } \\
\text { Treasury }\end{array}$ & - Eskom \\
\hline $\begin{array}{l}\text { National } \\
\text { Treasury } \\
\text { Fundudzi } \\
\text { reports, } \\
\text { related to } \\
\text { Eskom and } \\
\text { Transnet (x3) }\end{array}$ & $\begin{array}{l}\text { Final reports } \\
\text { compiled in } \\
\text { November } 2018 \\
\text { and released to } \\
\text { the public shortly } \\
\text { thereafter. }\end{array}$ & $\begin{array}{l}\text { Investigations requested by National Treasury } \\
\text { of alleged corruption at Transnet and Eskom. } \\
\text { The three reports focused on Eskom (general), } \\
\text { the contracts related to Trillian/McKinsey and } \\
\text { Transnet Locomotives. }\end{array}$ & $\begin{array}{l}\text { - National } \\
\text { Treasury } \\
\text { Fundudzi }\end{array}$ & $\begin{array}{l}\text { - Eskom } \\
\text { - Transnet }\end{array}$ \\
\hline \multirow[t]{2}{*}{$\begin{array}{l}\text { Transnet } \\
\text { Locomotive } \\
\text { Contracts }\end{array}$} & \multirow[t]{2}{*}{$\begin{array}{l}\text { Investigations } \\
\text { commenced in } \\
\text { December } 2017 \\
\text { and reports on } \\
\text { findings submitted } \\
\text { during } 2018 \text {. }\end{array}$} & $\begin{array}{l}\text { Werksmans Attorneys was appointed in } \\
\text { December } 2017 \text { to undertake an investigation } \\
\text { into the } 1064 \text { Transnet Locomotives } \\
\text { procurement process, however, the investigation } \\
\text { was halted. No report in the public domain. }\end{array}$ & - Werksmans & - Transnet \\
\hline & & $\begin{array}{l}\text { Mncedisi Ndlovu \& Sedumedi (MNS) Attorneys } \\
\text { was then appointed to investigate } 1064 \\
\text { locomotives procurement process. The report } \\
\text { is not in the public domain, but media indicates } \\
\text { that recommendations mirror the Werksmans' } \\
\text { findings and recommends that Molefe face } \\
\text { criminal charges. }\end{array}$ & $\begin{array}{l}\text { - Mncedisi } \\
\text { Ndlovu \& } \\
\text { Sedumedi }\end{array}$ & - Transnet \\
\hline $\begin{array}{l}\text { Inquiry into } \\
\text { State Capture } \\
\text { at Transnet } \\
\text { and Denel }\end{array}$ & $\begin{array}{l}\text { In June } 2017, \\
\text { Parliament directed } \\
4 \text { committees to } \\
\text { investigate state } \\
\text { capture. Committee } \\
\text { hearings were not } \\
\text { completed. }\end{array}$ & $\begin{array}{l}\text { A detailed information booklet was prepared } \\
\text { in relation to Transnet, however, hearings were } \\
\text { not held before the end of term of Parliament. } \\
\text { Following National elections in } 2019 \text {, it } \\
\text { was decided that outstanding Inquiries into } \\
\text { state capture be postponed indefinitely until } \\
\text { conclusion of the Zondo Commission. }\end{array}$ & $\begin{array}{l}\text { - Portfolio } \\
\text { Committee } \\
\text { on Public } \\
\text { Enterprises }\end{array}$ & $\begin{array}{l}\text { - Transnet } \\
\text { - Denel }\end{array}$ \\
\hline
\end{tabular}




\begin{tabular}{|c|c|c|c|c|}
\hline $\begin{array}{l}\text { Case Study } \\
\text { in State } \\
\text { Capture }\end{array}$ & Status & Summary Description & $\begin{array}{l}\text { Investigation } \\
\text { Body / } \\
\text { Source of } \\
\text { Evidence }\end{array}$ & $\begin{array}{l}\text { Government } \\
\text { Entity } \\
\text { Implicated }\end{array}$ \\
\hline \multicolumn{5}{|c|}{ Scandals Connected to Jacob Zuma, Guptas, Other Key Networks and ANC Politics } \\
\hline \multicolumn{5}{|c|}{ Law Enforcement and the Security Cluster } \\
\hline $\begin{array}{l}\text { Enquiry into } \\
\text { Jiba and } \\
\text { Mrwebi's } \\
\text { fitness to } \\
\text { hold office } \\
\text { at NPA }\end{array}$ & $\begin{array}{l}\text { Established in } \\
\text { November } 2018 . \\
\text { Report was issued } \\
\text { in April } 2019 .\end{array}$ & $\begin{array}{l}\text { Presidential Enquiry into the fitness to hold } \\
\text { office of suspended NPA senior advocates } \\
\text { Nomgcobo Jiba and Lawrence Mrwebi. NPA's } \\
\text { deputy head Jiba, and Mrwebi, the head of } \\
\text { the Specialised Commercial Crimes Unit, were } \\
\text { suspended in October } 2018 \text { by President Cyril } \\
\text { Ramaphosa. The Inquiry was headed by retired } \\
\text { Constitutional Court Justice Yvonne Mokgoro. } \\
\text { Jiba and Mrwebi were accused of improper } \\
\text { conduct in their handling of cases involving } \\
\text { former crime intelligence head Richard Mdluli, } \\
\text { as well as former KwaZulu-Natal Hawks boss } \\
\text { Johan Booysen. }\end{array}$ & $\begin{array}{c}\text { - Mokgoro } \\
\text { Enquiry }\end{array}$ & $\begin{array}{l}\text { - } \text { National } \\
\text { Prosecuting } \\
\text { Authority }\end{array}$ \\
\hline $\begin{array}{l}\text { High-Level } \\
\text { Review Panel } \\
\text { on the State } \\
\text { Security } \\
\text { Agency (SSA) }\end{array}$ & $\begin{array}{l}\text { Established in June } \\
2018 \text { and final } \\
\text { report was sent to } \\
\text { the President in } \\
\text { December } 2018 .\end{array}$ & $\begin{array}{l}\text { The High-Level Review Panel into the SSA } \\
\text { was established by President Ramaphosa in } \\
\text { June 2018. The key finding was a serious } \\
\text { politicisation and factionalisation of the } \\
\text { intelligence community over the past decade } \\
\text { or more. This resulted in "an almost complete } \\
\text { disregard for the Constitution, policy, legislation } \\
\text { and other prescripts, and [turned] our civilian } \\
\text { intelligence community into a private resource } \\
\text { to serve the political and personal interests of } \\
\text { particular individuals" (High-Level Review Panel } \\
\text { on the SSA, 2018, p. ii). }\end{array}$ & $\begin{array}{l}\text { - Review } \\
\text { Panel } \\
\text { established } \\
\text { by President } \\
\text { Ramaphosa }\end{array}$ & - SSA \\
\hline $\begin{array}{l}\text { Various court } \\
\text { cases against } \\
\text { persons } \\
\text { within law } \\
\text { enforcement }\end{array}$ & Ongoing. & $\begin{array}{l}\text { Though testimony and evidence have been } \\
\text { presented at the Zondo Commission, it is } \\
\text { understood that no definitive findings will be } \\
\text { made regarding the capture of law enforcement } \\
\text { under the Zuma administration. Since } 2012 \\
\text { onwards, there were several court cases } \\
\text { that were pursued against individuals in law } \\
\text { enforcement, all of which have been either } \\
\text { dismissed or withdrawn. Most noteworthy are } \\
\text { the cases involved, amongst others: Anwa } \\
\text { Dramat and Shadrack Sibiya of the Hawks } \\
\text { (and Robert McBride from Independent Police } \\
\text { Investigative Directorate [IPID]) for allegations } \\
\text { related to the "Zimbabwean rendition" matter; } \\
\text { Johan Booysen for alleged racketeering as part } \\
\text { of "Cato Manor hit squad"; and the various } \\
\text { senior officials accused of being part of the } \\
\text { "rogue" intelligence unit at SARS. Other court } \\
\text { cases that have provided significant evidence } \\
\text { indicating the capture of law enforcement relate } \\
\text { to the irregular appointed allies of the Shadow } \\
\text { State capture network or the irrational removal } \\
\text { of potential opponents holding senior positions } \\
\text { in law enforcement. Example is the irregular } \\
\text { removal of Mxolisi Nxasana as National Director } \\
\text { of Public Prosecutions (NDPP). }\end{array}$ & $\begin{array}{l}\text { - Various } \\
\text { court cases, } \\
\text { proceedings } \\
\text { in Parlia- } \\
\text { ment } \\
\text { - Zondo } \\
\text { Commission }\end{array}$ & $\begin{array}{l}\text { - NPA } \\
\text { - SAPS } \\
\text { - Hawks } \\
\text { - IPID }\end{array}$ \\
\hline
\end{tabular}




\begin{tabular}{|c|c|c|c|c|}
\hline $\begin{array}{l}\text { Case Study } \\
\text { in State } \\
\text { Capture }\end{array}$ & Status & Summary Description & $\begin{array}{l}\text { Investigation } \\
\text { Body / } \\
\text { Source of } \\
\text { Evidence }\end{array}$ & $\begin{array}{l}\text { Government } \\
\text { Entity } \\
\text { Implicated }\end{array}$ \\
\hline \multicolumn{5}{|c|}{ Scandals Connected to Jacob Zuma, Guptas, Other Key Networks and ANC Politics } \\
\hline \multicolumn{5}{|c|}{ Investigations concerning Private Sector } \\
\hline $\begin{array}{l}\text { Budlender } \\
\text { report on } \\
\text { Trillian }\end{array}$ & $\begin{array}{l}\text { Released in } \\
\text { June } 2017 .\end{array}$ & $\begin{array}{l}\text { Trillian Holdings Board appointed Geoff } \\
\text { Budlender SC to undertake investigations into } \\
\text { State Capture allegations at Trillian Capital. } \\
\text { Detailed accounts from whistle-blowers } \\
\text { highlighted how information was withheld by } \\
\text { senior management at Trillian. }\end{array}$ & - Trillion & - Eskom \\
\hline $\begin{array}{l}\text { Collapse of } \\
\text { VBS Mutual } \\
\text { Bank }\end{array}$ & $\begin{array}{l}\text { Investigation } \\
\text { launched in } \\
\text { April } 2018 \text { and } \\
\text { the report was } \\
\text { released in } \\
\text { October } 2018 .\end{array}$ & $\begin{array}{l}\text { Minister of Finance placed VBS under } \\
\text { curatorship with effect from } 11 \text { March 2018. In } \\
\text { April 2018, the Deputy Governor of the South } \\
\text { African Reserve Bank instituted an investigation } \\
\text { into VBS. The outcomes of the investigation } \\
\text { showed blatant fraud and corruption by senior } \\
\text { executives/Board and how they extracted } \\
\text { money from the bank. Municipal funds were } \\
\text { illegally deposited with VBS (senior ANC and } \\
\text { EFF politicians have been implicated). }\end{array}$ & $\begin{array}{l}\text { - SARB } \\
\text { investiga- } \\
\text { tion report } \\
\text { VBS Mutual } \\
\text { Bank - The } \\
\text { Great Bank } \\
\text { Heist }\end{array}$ & $\begin{array}{l}\text { - Several } \\
\text { Provincial and } \\
\text { Municipal } \\
\text { Officials } \\
\text { (Limpopo } \\
\text { Government) } \\
\text { - SOEs } \\
\text { (particularly } \\
\text { PRASA) }\end{array}$ \\
\hline $\begin{array}{l}\text { SA Institute } \\
\text { of Chartered } \\
\text { Accountants' } \\
\text { (SAICA) } \\
\text { investigation } \\
\text { into KPMG }\end{array}$ & $\begin{array}{l}\text { Final report was } \\
\text { handed to SAICA in } \\
\text { December } 2018 .\end{array}$ & $\begin{array}{l}\text { SA Institute of Chartered Accountants (SAICA) } \\
\text { established an Inquiry to investigate state } \\
\text { capture related allegations of misconduct of its } \\
\text { members who worked for KPMG. The Inquiry } \\
\text { chaired by advocate Dumisa Ntsebeza held } \\
\text { public hearings and handed its final report to } \\
\text { SAICA in December 2018. Indications are that } \\
\text { the final report will not be made public until all } \\
\text { investigations and disciplinary hearings have } \\
\text { been finalised. }\end{array}$ & - SAICA & - Guptas \\
\hline Bell Pottinger & $\begin{array}{l}2017 \text { investigation } \\
\text { by PRCA. }\end{array}$ & $\begin{array}{l}\text { In 2016, the Guptas appointed British PR } \\
\text { company, Bell Pottinger, who developed and } \\
\text { promoted a campaign that underpinned the RET } \\
\text { and WMC narratives. In 2017, there was an } \\
\text { independent law firm review by Herbert Smith } \\
\text { Freehills resulting in Bell Pottinger's expulsion } \\
\text { from the Public Relations and Communications } \\
\text { Association (PRCA). }\end{array}$ & $\begin{array}{l}\text { - PRCA } \\
\text { - GuptaLeaks } \\
\text { - Ongoing } \\
\text { research } \\
\text { on disinfor- } \\
\text { mation }\end{array}$ & - Guptas \\
\hline
\end{tabular}

